\title{
Intrastrand Self-complementary Sequences in Bacillus subtilis DNA
}

\author{
By DENISE A. GALLOWAY* AND RIVKA RUDNER $\dagger$ \\ Hunter College of the City University of New York, 695 Park Avenue, \\ New York, New York 10021, U.S.A.
}

(Received 24 July 1978; revised 16 September 1978)

\begin{abstract}
Intrastrand self-complementary sequences have been isolated from the DNA of Bacillus subtilis by hydroxyapatite (HA) chromatography following thermal renaturation of strands separated by chromatography on methylated albumin-kieselguhr (MAK). The intrastrand structures derived from the MAK H strand (HA HII) were biologically active showing transforming activity for a wide variety of markers, as well as hybridization to both pulselabelled and ribosomal RNA. Removal of regions of single-strand DNA with S1 nuclease did not significantly alter the biological activity of the self-annealed molecules. The overall efficiency of transformation and hybridization of the intrastrand self-annealing DNA was low suggesting that many sequences in the population are neither active in transformation to prototrophy nor transcribed into RNA.
\end{abstract}

\section{INTRODUCTION}

The presence of self-complementary sequences is a widespread phenomenon, occurring in the DNA of higher eukaryotes (Wilson \& Thomas, 1974), in bacteriophages M13 (Forsheit \& Ray, 1970), fd (Schaller et al., 1969) and f1 (Shishido et al., 1969), and in bacterial plasmids (Sharp et al., 1973). Kato et al. (1974) have reported that 2 to $8 \%$ of the DNA from Escherichia coli is capable of intrastrand base pairing. In general, secondary structure in the DNA of prokaryotes is less well-characterized than in the DNAs of other organisms. The purpose of our studies was to characterize the intrastrand secondary structure found in the DNA of Bacillus subtilis and to investigate the possible biological implications of such structures.

Rudner \& Remeza (1973) have previously reported that intrastrand secondary structure can be detected in B. subtilis DNA. Strands of DNA were resolved by methylated albuminkieselguhr chromatography (Roger et al., 1966; Rudner et al., 1968, 1969) and the molecules which were capable of annealing to form secondary structures were separated from the rest of the DNA by hydroxyapatite chromatography (Bernardi, 1969; Rudner \& Remeza, 1973). The rate of formation of these structures was rapid and independent of DNA concentration indicating intrastrand reassociation (Rudner \& Remeza, 1973). Genetic markers which are widely scattered throughout the $B$. subtilis genome were transformed by the DNA which contained secondary structure suggesting that the location of such sequences is not unique. The biological nature of the self-annealing DNA has been further characterized using transformation assays and by hybridization of this DNA to mRNA and to purified species of stable RNA. DNA which had been digested with S1 nuclease to remove single-strand regions (Ando, 1966) was also analysed by these methods. We report here that the selfannealing DNA partly comprises sequences which are transcribed into RNA and which are active in DNA-mediated bacterial transformation; however, the DNA which forms intrastrand secondary structures also contains sequences which are biologically silent.

* Present address: Fred Hutchinson Cancer Research Center, 1124 Columbia Street, Seattle, Washington 98104, U.S.A.

$\dagger$ To whom reprint requests should be addressed. 


\section{METHODS}

Bacterial strains. Mutant derivatives of Bacillus subtilis 168 were used: A26 (ura-1), for the preparation of DNA and radioactively labelled RNA; BD-204 (hisB2 thy $A$ thyB), for the preparation of radioactively labelled DNA; BD-170 (thr-5 trpC2) and Mu8u5u16 (leu-8 metB5 purA16), as recipients in transformation assays.

Transformation assays. Competent cells were prepared by a modification of the two-step growth method of Anagnostopoulos \& Spizizen (1961). Media I and II were as described by Rudner et al. (1967). Cells were either used immediately or concentrated 10 -fold by centrifugation, adjusted to $10 \%$ (v/v) glycerol and frozen. DNA $(0.1 \mathrm{ml})$ was added to $0.9 \mathrm{ml}$ of competent cells and incubated for $30 \mathrm{~min}$ at $37^{\circ} \mathrm{C}$; then pancreatic DNAase (Worthington; $10 \mu \mathrm{g} \mathrm{ml}^{-1}$ in $0.2 \mathrm{M}-\mathrm{MgSO}_{4}$ ) was added. The cultures were diluted in saline and plated on selective media as described by Rudner et al. (1967).

Isolation, denaturation and strand separation of DNA. Bacillus subtilis DNA was extracted according to a modification (Rudner et al., 1967) of the Marmur (1961) procedure. It was denatured at concentrations of 25 to $40 \mu \mathrm{g} \mathrm{ml}^{-1}$ in alkali as described by Rudner et al. (1968). The strands of $B$. subtilis DNA were separated by methylated albumin-kieselguhr (MAK) chromatography using an intermittent salt gradient as described previously (Rudner et al., 1968, 1969; Rudner \& Remeza, 1973).

Hydroxyapatite chromatography of self-annealed DNA. The isolated strands of DNA obtained by MAK chromatography were self-annealed at $68^{\circ} \mathrm{C}$ for $2 \mathrm{~h}$ at the salt concentration at which the strands were eluted from the MAK column. The DNA was then dialysed against $0.05 \mathrm{M}$-sodium phosphate buffer (pH 6.7) and applied to hydroxyapatite (HA) columns $\left(1 \mathrm{~cm}\right.$ diam. $\times 1 \mathrm{~cm}$ per $A_{260}$ of DNA applied). The hydroxyapatite was prepared as described by Miyazawa \& Thomas (1965). The DNA was eluted with 250 to $300 \mathrm{ml}$ of a linear gradient of 0.05 to $0.5 \mathrm{M}$-sodium phosphate buffer (pH 6.7) at a flow rate of $30 \mathrm{ml} \mathrm{h}^{-1}$.

Digestion with $S 1$ nuclease. S1 nuclease isolated from Aspergillus oryzae (Ando, 1966) was purchased from Miles Laboratories. The reaction mixture contained 0.3 mM-sodium acetate $(\mathrm{pH} 4.5), 1 \mu \mathrm{M}_{-}-\mathrm{ZnCl}_{2}, 0 \cdot 1 \mathrm{M}-$ $\mathrm{NaCl}, 20 \mu \mathrm{g}$ sheared, denatured calf thymus DNA ml${ }^{-1}$, radioactive DNA, and 500 units of enzyme (as determined by Miles Laboratories). The mixture was incubated at $37^{\circ} \mathrm{C}$ for $1 \mathrm{~h}$. Samples were then removed and either precipitated with $10 \%(\mathrm{w} / \mathrm{v})$ trichloroacetic acid and prepared for radioactive counting, or extracted twice with phenol and used in transformation or hybridization assays.

Isolation and fractionation of $R N A$. Two [ $\left.{ }^{3} \mathrm{H}\right]$ uridine-labelled RNA preparations isolated from exponentially growing vegetative cells were used: (i) from cells pulse-labelled for $3 \mathrm{~min}$; (ii) from cells labelled continuously for 3 to 4 generations followed by treatment with actinomycin D. Both RNA preparations were made by Dr Yoshiko Setoguchi according to published procedures (Margulies et al., 1970, 1971). The long-labelled RNA was fractionated into components by MAK chromatography as described by Margulies et al. (1970).

Hybridization to RNA. Two methods of DNA-RNA hybridization were used: (i) the liquid technique as described by Nygaard \& Hall (1963) and modified by Kennell \& Kotoulas (1968); (ii) the filter technique described by Gillespie \& Spiegelman (1965). In the liquid method, each reaction mixture contained not less than $2 \mu \mathrm{g} \mathrm{DNA} \mathrm{ml}^{-1}$ and [ $\left.{ }^{3} \mathrm{H}\right]$ uridine-labelled RNA in a total volume of 0.05 to $0.10 \mathrm{ml}$. The hybridization was carried out at $68{ }^{\circ} \mathrm{C}$ for $18 \mathrm{~h}$ in $6 \times \mathrm{SSC}$ buffer (SSC buffer is $0.15 \mathrm{M}-\mathrm{NaCl} / 0.015 \mathrm{M}$-sodium citrate, pH 7.0); it was terminated by chilling on ice and diluting with $10 \mathrm{ml} 2 \times$ SSC buffer. The hybrids were collected on nitrocellulose filters (B-6, $24 \mathrm{~mm}$; Schleicher \& Schuell Co.), washed with $100 \mathrm{ml} 2 \times$ SSC buffer, treated with RNAase A (20 $\left.\mu \mathrm{g} \mathrm{ml}^{-1}\right)$ and RNAase T1 (20 units $\left.\mathrm{ml}^{-1}\right)$ (both from Worthington) for $1 \mathrm{~h}$ at room temperature, washed again with $100 \mathrm{ml} 2 \times \mathrm{SSC}$ buffer, dried and counted in a toluene-based scintillant.

In the filter method, $10 \mu \mathrm{g}{ }^{32} \mathrm{P}$-labelled DNA were slowly added to a nitrocellulose filter which previously had been soaked in $0 \cdot 1 \mathrm{M}-\mathrm{KOH}$ for $30 \mathrm{~min}$ and then in $2 \times \mathrm{SSC}$ buffer for $30 \mathrm{~min}$. The filters containing DNA were washed with $100 \mathrm{ml} 2 \times \mathrm{SSC}$ buffer, dried at room temperature and baked for $2 \mathrm{~h}$ at $80^{\circ} \mathrm{C}$ in vacuo. The dried filters were incubated in scintillation vials with [ $\left.{ }^{3} \mathrm{H}\right]$ uridine-labelled RNA in $6 \times$ SSC buffer in a total volume of $1.0 \mathrm{ml}$, at $68^{\circ} \mathrm{C}$ for $16 \mathrm{~h}$. The reactions were terminated and filters were washed, treated with RNAases and prepared for radioactive counting as described above.

Sedimentation velocity centrifugation. Sedimentation velocity studies were performed using a Beckman model E Analytical Ultracentrifuge equipped with ultraviolet absorption optics. A $30 \mathrm{~mm}$ single sector cell, Kel-F $4^{\circ}$ centrepiece and quartz windows were used. A Beckman model RB Analytrol was used to obtain densitometer tracings of the photographic films. Centrifugation was done at $24000 \mathrm{rev} . \mathrm{min}^{-1}$ at $20^{\circ} \mathrm{C}$ with DNA at 8 to $30 \mu \mathrm{g} \mathrm{ml}^{-1}$ in $1 \times \mathrm{SSC} / 0 \cdot 2 \mathrm{M}-\mathrm{NaOH}$. (The native DNA sample was kept at neutral $\mathrm{pH}$.) The sedimentation coefficient was obtained from the relation: $s=\left(1 / w^{2}\right)(\mathrm{d} \ln x / \mathrm{d} t)$ where $\mathrm{d} \ln x / \mathrm{d} t$ is the slope of the line of the natural logarithm of the distance from the centre of rotation to the boundary versus the time of 
sedimentation (Svedberg \& Pederson, 1940). The molecular weights of the DNAs were estimated according to Studier (1965):

$$
\text { for native DNA } s_{20, w}^{0}=0.0882 M^{0.346} \text { for alkaline DNA } s_{20, w}^{0}=0.0528 M^{0.400}
$$

\section{RESULTS}

\section{Transforming activity of fractionated DNA}

Alkali-denatured $B$. subtilis DNA has been separated into two fractions, designated $\mathrm{L}$ and $\mathrm{H}$, by MAK chromatography (Fig. $1 a$ ) and the complementarity of these fractions has been well substantiated (Rudner et al., 1968, 1969; Karkas et al., 1968). In addition, a minor component (M) of 'native-like' molecules of DNA containing covalent cross-links (Alberts, 1968) elutes at a lower salt molarity than the $L$ fraction. All of the residual transforming activity of denatured $B$. subtilis DNA is associated with the cross-linked molecules (Rownd et al., 1968). Another distinctly different population of molecules which has transforming

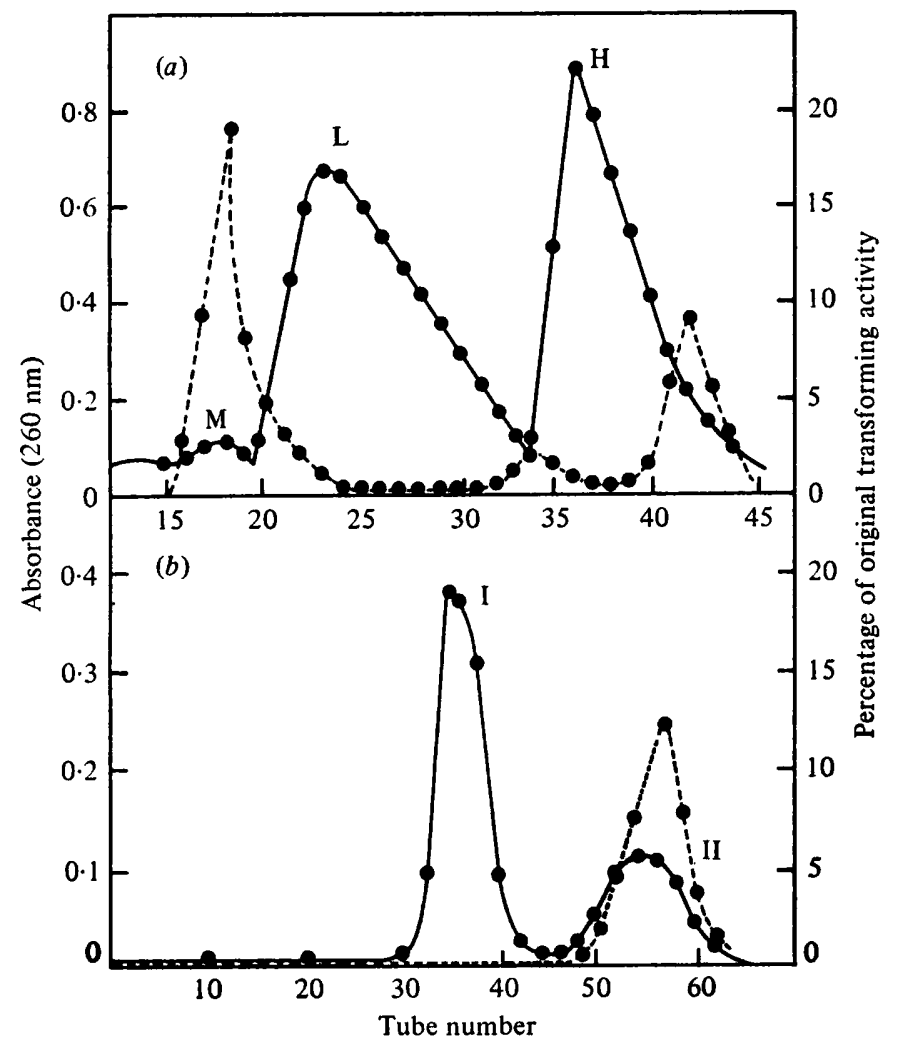

Fig. 1. Transforming activity following thermal renaturation of individual fractions of DNA separated by MAK $(a)$ and HA $(b)$ chromatography.

(a) Alkali-denatured DNA $(3.7 \mathrm{mg}$ ) was applied in $0.7 \mathrm{M}-\mathrm{NaCl}$ in $0.05 \mathrm{M}$-sodium phosphate buffer (pH 6.8) and eluted with $500 \mathrm{ml}$ of 0.7 to $1.5 \mathrm{M}-\mathrm{NaCl}$. The gradient was interrupted at tube 21 and re-established at tube 26 . Recovery was $76.3 \%$ with an $\mathrm{L} / \mathrm{H}$ ratio of 1.15 as determined by $A_{260}$ (- - Individual fractions were heated at $68{ }^{\circ} \mathrm{C}$ for $2 \mathrm{~h}$ and adjusted to $5 \mu \mathrm{g} \mathrm{ml}^{-1}$. Transformation for $t h r-5$ was assayed using BD170 recipient cells and $0.5 \mu \mathrm{g} \mathrm{DNA} \mathrm{ml}^{-1}$. At $0.5 \mu \mathrm{g} \mathrm{ml}^{-1}$ the activity of native DNA was $2.3 \times 10^{5}$ transformants $\mathrm{ml}^{-1}$. The transforming activity $(--)$ is expressed as a percentage of the original transforming activity.

(b) Fractions 38 to 45 of MAK H DNA were renatured at $68{ }^{\circ} \mathrm{C}$, dialysed against $0.05 \mathrm{M}$-sodium phosphate buffer (pH 6.7), adsorbed to a $6 \mathrm{~cm} \mathrm{HA}$ column, and eluted with $250 \mathrm{ml}$ of 0.05 to $0.5 \mathrm{M}$-sodium phosphate buffer $(\mathrm{pH} 6.7)$. The recovery $(-)$ as a percentage of the input was: total, $72 \cdot 3 ; \mathrm{HI}, 47 \cdot 0 ; \mathrm{HII}, 23 \cdot 0$. The transforming activity (--) was assayed as in $(a)$. 
Table 1. Effect of $S 1$ nuclease digestion on transforming activity

Unlabelled DNA $\left(10 \mu \mathrm{g} \mathrm{ml}^{-1}\right)$ was incubated for $60 \mathrm{~min}$ at $37^{\circ} \mathrm{C}$ in the $\mathrm{S} 1$ assay mixture with or without S1 enzyme. The DNAs were all assayed at a concentration of $0.5 \mu \mathrm{g} \mathrm{ml}^{-1}$.

Percentage of initial transforming activity

$\begin{array}{lcccc} & \text { purAl6 } & \text { leu-8 } & \text { metB5 } & \text { thr }-5 \\ \text { DNA fraction } & \left(1.2 \times 10^{5}\right) * & \left(6.3 \times 10^{4}\right) * & \left(6.9 \times 10^{5}\right) * & \left(2.6 \times 10^{5}\right) * \\ \text { Native } & 100 & 100 & 100 & 100 \\ \text { Native+S1 } & 93.6 & 82.6 & 88.3 & 84.1 \\ \text { HA HII } & 14.2 & 6.8 & 8.2 & 9.7 \\ \text { HA HII +S1 } & 7.8 & 0.7 & 3.6 & 4.7\end{array}$

* Number of transformants $\mathrm{ml}^{-1}$ with native DNA assayed for the various markers.

Table 2. Extent of $S 1$ nuclease digestion of various fractions of DNA

$\left[{ }^{3} \mathrm{H}\right]$ Thymidine-labelled DNA ( $2 \mu \mathrm{g} \mathrm{ml}^{-1}$, sp. act. 51200 c.p.m. $\left.\mu \mathrm{g}^{-1}\right)$ and $50 \mu \mathrm{g}$ sheared, denatured calf thymus DNA were incubated for $60 \mathrm{~min}$ at $37^{\circ} \mathrm{C}$ in the $\mathrm{S} 1$ assay mixture containing $0 \cdot 1 \mathrm{M}-\mathrm{NaCl}$ (total vol. $2.5 \mathrm{ml}$ ) with 500 units of enzyme: samples $(0.2 \mathrm{ml})$, in triplicate, were removed and precipitated with an equal volume of ice-cold $10 \%$ trichloroacetic acid (TCA).

\begin{tabular}{lrc} 
& \multicolumn{2}{c}{$\begin{array}{c}\text { Radioactivity in } \\
\text { TCA-precipitated DNA }\end{array}$} \\
\cline { 2 - 3 } [ ${ }^{3}$ H]DNA fraction & c.p.m. & $\%$ of original \\
Native & 18500 & 90 \\
Denatured & 3100 & 15 \\
MAK H & 4100 & 20 \\
HA HI & 3700 & 18 \\
HA HII & 12200 & 60
\end{tabular}

activity following thermal renaturation $\left(68^{\circ} \mathrm{C}\right)$ has been described (Rudner \& Remeza, 1973). This DNA reassociates with unimolecular kinetics, typical of intrastrand structures. Only the slowest eluting molecules of $\mathrm{H}$ strand DNA show an increased transforming activity following self-annealing (Fig. $1 a$ ).

Hydroxyapatite chromatography, which can separate double- and single-stranded DNA, was used to isolate the sequences which self-annealed from the rest of the DNA. Figure $1(b)$ shows the pattern obtained when the MAK H strand was self-annealed and eluted from a hydroxyapatite column with a linear salt gradient. The first fraction (HA HI) is entirely single-stranded while the second fraction (HA HII) contains double-stranded DNA. Only the second fraction of HA-fractionated DNA had transforming activity (Fig. 1b). Selfannealing of the $L$ strand also produced a fraction of DNA with intrastrand structure; however, these molecules showed virtually no transforming activity. HA HII DNA showed 6 to $10 \%$ of the transforming activity of native DNA. As shown in Table 1 and previously (Rudner \& Remeza, 1973), all of the markers assayed (purA16, leu-8, metB5 and thr-5) were transformed by HA HII DNA, suggesting that secondary structure is located throughout the chromosome.

Molecules of DNA which are retained by hydroxyapatite (e.g. HA HII) need not be perfectly helical but can have single-stranded tails or loops (Wilson \& Thomas, 1973). To determine whether the DNA sequence responsible for the transforming activity resides in the base-paired or single-stranded region of the HA HII molecules, the DNA was digested with S1 nuclease. The ionic strength is very important in controlling the specificity of this enzyme. Vogt (1973) found that $\mathrm{S} 1$ in $0.3 \mathrm{M}-\mathrm{NaCl}$ introduced one nick per 10 molecules of native $\lambda$ DNA, whereas in $0.05 \mathrm{M}-\mathrm{NaCl}$ it introduced one nick per molecule. Similarly, the endonucleolytic activity of $\mathrm{S} 1$ on single-stranded DNA is greater at low $\mathrm{NaCl}$ concentrations. Table 2 shows the extent of degradation of various DNAs by $\mathrm{S} 1$ nuclease in $0 \cdot 1 \mathrm{M}-\mathrm{NaCl}$ : 
Table 3. Hybridization of $M A K$ - and $H A$-fractionated $H$ strands to pulse-labelled $\left[{ }^{3} H\right] R N A$

${ }^{32}$ P-Labelled DNA (10 $\mu$ g; sp. act. 16600 c.p.m. $\mu \mathrm{g}^{-1}$ ) was added to a nitrocellulose filter and the amount immobilized on the filter was determined. Dried filters were incubated with $0.71 \mu \mathrm{g}$ of pulse-labelled [ $\left.{ }^{3} \mathrm{H}\right]$ RNA (sp. act. 55500 c.p.m. $\mu \mathrm{g}^{-1}$ ) in $6 \times \mathrm{SSC}$ buffer at $68^{\circ} \mathrm{C}$ for $16 \mathrm{~h}$. DNA fractions designated D- were thermally denatured at $100{ }^{\circ} \mathrm{C}$ for $10 \mathrm{~min}$ prior to immobilization on filters.

\begin{tabular}{lccc} 
DNA fraction & $\begin{array}{c}\text { DNA } \\
\text { immobilized } \\
(\mu \mathrm{g})\end{array}$ & \multicolumn{1}{c}{$\left[{ }^{3} \mathrm{H}\right] \mathrm{RNA}$.p.m. } & $\%$ of total \\
MAK H & $6 \cdot 7$ & 16300 & 41 \\
HA HI & $9 \cdot 0$ & 9200 & 23 \\
HA HII & $0 \cdot 8$ & 184 & $0 \cdot 5$ \\
D-HA HII & $8 \cdot 6$ & 2900 & $7 \cdot 3$ \\
D-HA H(I+II) & $8 \cdot 0$ & 12600 & 32 \\
D-HA HII + S1 & $6 \cdot 5$ & 2100 & $5 \cdot 4$
\end{tabular}

$60 \%$ of the HA HII DNA was resistant to S1 nuclease, whereas thermal denaturation profiles (data not shown) indicated that only $25 \%$ of HA HII DNA forms helical regions, suggesting that the resistant DNA contains single-stranded, presumably unpaired, loop regions. Thus the self-complementary sequences may more closely resemble the type of structures found in plasmid DNA (Sharp et al., 1973) than the hairpin structures with very small turnaround regions found in eukaryotic DNA (Wilson \& Thomas, 1974). With the exception of the leu-8 marker, all of the markers assayed were transformed at approximately $50 \%$ of their initial level by S1-treated HA HII DNA (Table 1). The leu- 8 marker is known to be highly sensitive to denaturation and to the competency of the recipients (R. Rudner, unpublished results). It is possible that the leucine gene is in a unique structural configuration that leaves it sensitive to nucleases. The retention of transforming activity by the HA HII DNA which is resistant to $\mathrm{S} 1$ digestion indicates that the intrastrand self-complementary sequences, or the loops between the regions, contain structural gene sequences which are directly active in biological transformation.

\section{Hybridization to pulse-labelled $\left[{ }^{3} H\right] R N A$}

RNA extracted from bacteria which had been labelled for 3 min with $\left[{ }^{3} \mathrm{H}\right]$ uridine while rapidly growing in the exponential phase was enriched for messenger transcripts: competition hybridization experiments showed the ribosomal RNA content to be $33 \%$ (Y. Setoguchi \& R. Rudner, unpublished results). Messenger RNA is known to be transcribed asymmetrically in $B$. subtilis, with $90 \%$ hybridizing to the MAK $\mathrm{H}$ strand and $10 \%$ to the MAK L strand (Margulies et al., 1971; Yamakawa \& Doi, 1971; DiCioccio \& Strauss, 1971). HA HII DNA which had been immobilized on nitrocellulose filters before or after digestion with S1 nuclease was hybridized to pulse-labelled RNA to determine the extent to which regions with secondary structure are transcribed during vegetative growth. The results of hybridization at a DNA/RNA ratio of 15:1 are given in Table 3. At this ratio, the percentage of RNA hybridized is $75 \%$ of the maximum. Thermally denatured HA HII DNA (designated D-HA HII) hybridized to pulse-labelled RNA poorly $(\mathbf{1 7 . 7 \%}$ ) in comparison with the original MAK $\mathrm{H}$ fraction indicating that much of the mRNA that is synthesized during the exponential phase of vegetative growth is not transcribed from sequences of HA HII DNA. There was no significant loss of hybridization following hydroxyapatite chromatography since a mixture of the fractions [D-HA $\mathrm{H}(\mathrm{I}+\mathrm{II})$ ] hybridized almost $(80 \%)$ as efficiently as the MAK H strand. The removal of single-strand DNA (D-HA HII + S1) did not significantly reduce the hybridization efficiency of this fraction of DNA indicating that the self-complementary sequences are transcribed at the same level as the rest of the DNA in the population. 
Table 4. Hybridization of $M A K$ - and $H A$-fractionated $H$ strands to stable $\left[{ }^{3} H\right] R N A$ ${ }^{32}$ P-Labelled DNA $(10 \mu \mathrm{g})$ was applied to a nitrocellulose filter and the dried filter was incubated with $\left.0.5 \mu \mathrm{g} \mathrm{[}{ }^{3} \mathrm{H}\right]$ RNA (sp. act. 20800 c.p.m. $\mu \mathrm{g}^{-1}$ ) in $6 \times \mathrm{SSC}$ buffer (total vol. $1 \mathrm{ml}$ ) at $68^{\circ} \mathrm{C}$ for $16 \mathrm{~h}$. HA HII fractions were thermally denatured at $100{ }^{\circ} \mathrm{C}$ for $10 \mathrm{~min}$ prior to immobilization on filters.

\begin{tabular}{lccc} 
& & \multicolumn{2}{c}{$\left[{ }^{3} \mathrm{H}\right] \mathrm{RNA}$ hybridized } \\
\cline { 3 - 4 } DNA fraction & RNA fraction & c.p.m. & $\%$ of total \\
MAK H & $23 \mathrm{~S}$ & 3200 & 25 \\
HA HI & $23 \mathrm{~S}$ & 1600 & 13 \\
D-HA HII & $23 \mathrm{~S}$ & 1100 & $8 \cdot 7$ \\
MAK H & $16 \mathrm{~S}$ & 1600 & 16 \\
HA HI & $16 \mathrm{~S}$ & 1600 & 16 \\
D-HA HII & $16 \mathrm{~S}$ & 1600 & 16 \\
MAK H & $5 \mathrm{~S}$ & 990 & 10 \\
HA HI & $5 \mathrm{~S}$ & 520 & $5 \cdot 2$ \\
D-HA HII & $5 \mathrm{~S}$ & 590 & $5 \cdot 9$ \\
MAK H & $4 \mathrm{~S}$ & 940 & 10 \\
HA HI & $4 \mathrm{~S}$ & 920 & 10 \\
D-HA HII & $4 \mathrm{~S}$ & 530 & $5 \cdot 8$
\end{tabular}

Table 5. Sedimentation values and estimated molecular weights of native and fractionated strands of $B$. subtilis DNA

\begin{tabular}{|c|c|c|}
\hline DNA fraction & $\begin{array}{l}10^{13} \times \text { Sedi- } \\
\text { mentation } \\
\text { coefficient }\end{array}$ & $\begin{array}{c}10^{-6} \times \\
\text { Molecular } \\
\text { weight }\end{array}$ \\
\hline Native & $25 \cdot 0$ & $12 \cdot 0$ \\
\hline Denatured & $21 \cdot 9$ & $3 \cdot 5$ \\
\hline MAK L & $18 \cdot 5$ & $2 \cdot 3$ \\
\hline MAK H & $21 \cdot 4$ & $3 \cdot 3$ \\
\hline $\mathrm{HA} \mathrm{HI}$ & $20 \cdot 1$ & $2 \cdot 8$ \\
\hline HA HII & $20 \cdot 2$ & $2 \cdot 9$ \\
\hline $\mathrm{HA} \mathrm{HII+S1}$ & $*$ & $1 \cdot 8$ \\
\hline
\end{tabular}

* Value obtained from TCA precipitation of S1-resistant DNA.

Hybridization to isolated components of stable RNA

Margulies et al. (1970) have shown that transcription of stable RNA components occurs entirely off the $\mathbf{H}$ strand of $B$. subtilis DNA. The hybridization pattern of the isolated RNA components $(23,16,5$ and $4 S)$ to the various $H$ strand DNA fractions is given in Table 4. At the DNA/RNA ratio used (20:1), the percentage of RNA hybridized is maximal. Both hydroxyapatite fractions of DNA (HI and HII) showed high levels of hybridization to stable RNA indicative of the conditions of DNA excess. The 5S and $16 \mathrm{~S}$ species hybridized equally well to both hydroxyapatite fractions while the $23 \mathrm{~S}$ and $4 \mathrm{~S}$ species did not. The wide range of hybridization efficiencies suggests that some portion of the ribosomal cistrons, or possibly their adjacent sequences, is composed of regions of DNA containing secondary structure.

\section{Molecular size of fractionated DNA}

The size of the DNA fractions was determined by sedimentation velocity centrifugation (Table 5). The MAK H strand fragments were larger than the MAK L fragments, consistent with the increased lability of the purine-rich L strand (Rudner \& Remeza, 1973). Both hydroxyapatite fractions showed the same sedimentation coefficient for a given strand. The HA HII fraction which has reduced biological activity has a molecular weight of around $3 \times 10^{6}$. Digestion of this fraction of DNA with S1 nuclease reduced its molecular weight by about $40 \%$ to greater than $1.8 \times 10^{6}$. 
DISCUSSION

Our studies confirm that, as in many other organisms, the DNA of B. subtilis contains intrastrand self-complementary sequences. The evidence that we obtained intrastrand selfcomplementary sequences rather than a mixture of $H$ and $L$ strand DNA, or crosslinked DNA, is twofold: (i) the position at which this DNA elutes from a MAK column is unusual (see Fig. 1a); (ii) the kinetics of reassociation are not instantaneous, as with crosslinked molecules, nor are they bimolecular, ruling out formation of $\mathrm{L}$ and $\mathrm{H}$ duplexes (Rudner \& Remeza, 1973). The self-complementary sequences comprise 5 to $10 \%$ of the genome as determined by the proportion of DNA resistant to digestion with S1 nuclease.

Transformation and hybridization analyses have shown that HA HII DNA has limited biological activity. That the late-eluting $\mathrm{H}$ strand DNA is able to transform only after thermal renaturation reflects the well-established requirement for double-stranded DNA for penetration into a competent bacterium. The biological activity of this fraction of DNA is low; the transformation frequency is 6 to $10 \%$ of that of native DNA and the hybridization efficiency to pulse-labelled RNA is $18 \%$ of that of the MAK H strand. These data indicate that HA HII DNA contains many sequences which are not active in transformation and that much of the RNA that is made during vegetative growth does not hybridize to HA HII DNA. Of the molecules which are transcribed or have transforming activity, removal of the singlestranded portion with S1 nuclease did not substantially alter their activity indicating that regions of DNA which are self-complementary can be coding sequences for structural genes. The low transforming activity of the HA HII DNA, both before and after treatment with S1 nuclease, is not a consequence of small size. The molecular weights of the DNAs are $3 \times 10^{6}$ and $1.8 \times 10^{6}$, respectively, well in excess of the minimum size requirement for transforming activity of $10^{6}$ (Morrison \& Guild, 1972).

Hybridization of HA HII DNA to stable RNA gave a wide range of efficiencies (between 35 and $100 \%$ of that of MAK H DNA). Doolittle \& Pace (1971) have shown that rRNA molecules are derived from a transcriptional unit consisting of 16S, 23S and 5S rRNA genes in that order. Secondary structure in the spacer and promotor regions between the units may account for the greater hybridization efficiency of HA HII DNA to 16S and 5S RNA. Alternatively, differences in secondary structure of the RNAs could affect the extent of hybridization.

Whether intrastrand self-complementary DNA sequences of the type described in this study are involved in the regulation of biological processes in B. subtilis is in the realm of speculation. There have been many proposals (Grier, 1966; Gilbert \& Müller-Hill, 1967; Sobell, 1972) that regulatory proteins, such as repressors, polymerases, recombinational enzymes etc., might recognize and bind to sequences of the type $\mathrm{ABCC}^{\prime} \mathrm{B}^{\prime} \mathrm{A}^{\prime}$. Self-complementary sequences with more extensive unpaired regions $\mathrm{ABC}$. . $\mathrm{C}^{\prime} \mathrm{B}^{\prime} \mathrm{A}^{\prime}$ have been described in the leader sequences in both prokaryotes (Lee \& Yanofsky, 1977) and animal viruses (Chow et al., 1977), at the ends of insertion elements (Ohtsubo \& Ohtsubo, 1978) and in several transposable DNA segments carrying antibiotic resistance genes (Kleckner et al., 1975; Heffron et al., 1975). It is possible that many modes of recombination occur through self-complementary sequences or that they are involved in the regulation of transcription. The studies reported here represent a first step in the isolation and characterization of intrastrand self-complementary sequences from $B$. subtilis.

We thank Douglas Testa for many helpful discussions and Madeline Szadkowski for typing the manuscript. This work was supported by PHS grant GM 16059 from NIH and by City University of New York Faculty Research Award nos. 10184 and 10566, and was in partial fulfilment of the requirements for the Ph.D. degree, the City University of New York, by D.A.G. 


\section{REFERENCES}

Alberts, B. M. (1968). Characterization of a naturally occurring, cross-linked fraction of DNA. II. Origin of the cross-linkage. Journal of Molecular Biology 32, 405-421.

Anagnostopoulos, C. \& Spizizen, J. (1961). Requirements for transformation in Bacillus subtilis. Journal of Bacteriology 81, 741-746.

Ando, T. (1966). A nuclease specific for heatdenatured DNA isolated from a product of Aspergillus oryzae. Biochimica et biophysica acta 144, 158-168.

Bernardi, G. (1969). Chromatography of nucleic acids on hydroxyapatite. Biochimica et biophysica acta 174, 423-457.

Chow, L. T., Gelinas, R. E., Broker, T. R. \& RoBERTs, R. J. (1977). An amazing sequence arrangement at the $5^{\prime}$ ends of adenovirus- 2 messenger RNA. Cell 12, 1-8.

DiCioccio, R. A. \& Strauss, N. (1971). Annealing studies of transcription in B. subtilis. Biochemical and Biophysical Research Communications 45, 212-218.

Doolittle, W. F. \& PACl, N. R. (1971). Transcriptional organization of the ribosomal RNA cistrons in Escherichia coli. Proceedings of the National Academy of Sciences of the United States of America 68, 1786-1790.

ForsheIT, A. B. \& RAY, D. S. (1970). Conformations of the single stranded DNA of bacteriophage M13. Proceedings of the National Academy of Sciences of the United States of America 67, 1534-1541.

GilberT, W. \& Müller-Hild, B. (1967). The lac operator in DNA. Proceedings of the National Academy of Sciences of the United States of America 58, 2415-2421.

GillesPIE, D. \& SPIEGElman, S. (1965). A quantitative assay for DNA-RNA hybrids with DNA immobilized on a membrane. Journal of Molecular Biology 12, 829-842.

GRIER, A. (1966). Model for DNA and protein interactions and the function of the operator. Nature, London 212, 1480-1481.

HefFron, F., Rúbens, C. \& Falkow, S. (1975). Translocation of a plasmid DNA sequence which mediates ampicillin resistance: molecular nature and specificity of insertion. Proceedings of the National Academy of Sciences of the United States of America 72, 3623-3627.

KARKas, J., RUdNeR, R. \& Chargaff, E. (1968). Separation of $B$. subtilis DNA into complementary strands. II. Template properties. Proceedings of the National Academy of Sciences of the United States of America 60, 915-920.

Kato, A. C., Borstad, L., Fraser, M. J. \& DENHARDT, D. T. (1974). Isolation of repeated and self-complementary sequences from $E$. coli DNA. Nucleic Acid Research 1, 1539-1549.

Kennell, D. \& Kotoulas, A. (1968). Titration of the gene sites on DNA by DNA-RNA hybridization. Journal of Molecular Biology 34, 71-84.

KleCKNER, N., Chan, R. K., Tye, B.-K. \& Botstein, D. (1975). Mutagenesis by insertion of a drug- resistance element carrying an inverted repetition. Journal of Molecular Biology 97, 561-575.

LeE, F. \& YANOFSKY, C. (1977). Transcription termination at the trp operon attenuators of Escherichia coli and Salmonella typhimurium: RNA secondary structure and regulation of termination. Proceedings of the National Academy of Sciences of the United States of America 74, 4365-4369.

Margulies, L., Remeza, V. \& RudneR, R. (1970). Asymmetric template function of microbial deoxyribonucleic acids: transcription of ribosomal and soluble ribonucleic acids. Journal of Bacterio$\log y$ 103, 560-568.

Margulies, L., Remeza, V. \& Rudner, R. (1971). Asymmetric template function of microbial deoxyribonucleic acids: transcription of messenger ribonucleic acid. Journal of Bacteriology 107, 610-617.

MARMUR, J. (1961). A procedure for the isolation of deoxyribonucleic acid from micro-organisms. Journal of Molecular Biology 3, 208-218.

Miyazawa, Y. \& Thomas, C. A., JR (1965). Nucleotide composition of short segments of DNA molecules. Journal of Molecular Biology 11, 223-237.

Morrison, D. A. \& GUILD, W. R. (1972). Activity of deoxyribonucleic acid fragments of defined size in Bacillus subtilis transformation. Journal of Bacteriology 112, 220-223.

NygaARD, A. P. \& Hall, B. D. (1963). A method for the detection of RNA-DNA complexes. Biochemical and Biophysical Research Communications 12, 98-104.

Ohtsubo, H. \& Ohtsubo, E. (1978). Nucleotide sequence of an insertion element, IS 1. Proceedings of the National Academy of Sciences of the United States of America 75, 615-619.

Roger, M., BeckmanN, C. O. \& Hotchkiss, R. D. (1966). Separation of native and denatured fractions from partially denatured pneumococcal DNA. Journal of Molecular Biology 18, 156-173.

Rownd, R., Green, D. M., Sternglanz, R. \& DotY, P. (1968). Origin of residual transforming activity of denatured Bacillus subtilis DNA. Journal of Molecular Biology 32, 369-377.

RUDNER, R. \& REMEZA, V. (1973). Chromatographically fractionated complementary strands of Bacillus subtilis deoxyribonucleic acid: biological properties. Journal of Bacteriology 113, 739-753.

RudNER, R., LiN, H. J., Hoffman, S. E. M. \& Chargaff, E. (1967). Studies on the loss and restoration of transforming activity of the DNA of Bacillus subtilis. Biochimica et biophysica acta 149, 199-219.

Rúdner, R., Karkas, J. \& Chargaff, E. (1968). Separation of $B$. subtilis DNA into complementary strands. I. Biological properties. Proceedings of the National Academy of Sciences of the United States of America 60, 630-635.

Rudner, R., KaRKas, J. \& Chargaff, E. (1969). Separation of micFobial DNA into complementary strands. Proceedings of the National Academy of Sciences of the United States of America 63, 152-159. 
Schaller, H., Voss, H. \& Gucker, S. (1969). Structure of the DNA of bacteriophage fd. II. Isolation and characterization of DNA fraction with double-strand-like properties. Journal of Molecular Biology 44, 445-458.

Sharp, P. A., Cohen, S. N. \& Davidson, N. (1973). Electron microscopic heteroduplex studies of sequence relations among plasmids of $E$. coli. Journal of Molecular Biology 75, 235-255.

Shishido, F., Kato, M. \& IKEDA, Y. (1969). On the two DNases, $\mathrm{K} 1$ and $\mathrm{K} 2$, isolated from the mycelia of Aspergillus oryzae. Journal of Biochemistry 65, 49-53.

SobelL, H. M. (1972). Molecular mechanism for genetic recombination. Proceedings of the National Academy of Sciences of the United States of America 69, 2483-2487.

StudiER, F W. (1965). Sedimentation studies of the size and shape of DNA. Journal of Molecular Biology 11, 373-390.

SvedberG, T. \& Pederson, K. O. (1940). The Ultracentrifuge. Oxford: Clarendon Press.

VoGr, V. (1973). Purification and further properties of single strand specific nuclease from Aspergillus oryzae. European Journal of Biochemistry 33, 192-200.

Wilson, D. A. \& Thomas, C. A., JR (1973). Hydroxyapatite chromatography of short double-helical DNA. Biochimica et biophysica acta 331, 333-340.

Wilson, D. A. \& Thomas, C. A., JR (1974). Palindromes in chromosomes. Journal of Molecular Biology 84, 115-138.

Yamakawa, T. \& Dor, R. H. (1971). Preferential transcription of Bacillus subtilis light deoxyribonucleic acid strands during sporulation. Journal of Bacteriology 106, 305-310. 